\title{
A Communicative Analysis of Language Functions in the Chinese as a Foreign Language (CFL) Textbooks: The Case of Happy Chinese
}

\author{
Percia T. Adil, Princess H. Policarpio, Cavin F. Pamintuan* \\ College of Education, Angeles University Foundation, 2009, Angeles City, Philippines
}

Received May 7, 2020 ; Revised June 27, 2020; Accepted July 20, 2020

Copyright $(2020$ by authors, all rights reserved. Authors agree that this article remains permanently open access under the terms of the Creative Commons Attribution License 4.0 International License

\begin{abstract}
This study focused on analyzing the utterances in each dialogue embedded in the Chinese as Foreign Language (CFL) textbooks entitled "Happy Chinese." These books are used in Philippine public high schools under the Special Program for Foreign Language Mandarin. This study utilized the mixed-methods research design and Jakobson's communicative language function model in the analysis and interpretation of quantitative and qualitative data. The results showed that language functions are not equally and fairly distributed in every textbook. The results of this study revealed that in Textbooks 1 and 2, the most observed language function is referential, while in Textbook 3 , the most observed language function is phatic. It is observed in all three textbooks that metalinguistic and poetic functions are less frequent. Thus, these textbooks in terms of their communicative ability do not provide comprehensive support for all the six (6) language functions. Hence, the study recommends textbook developers to consider communicative language function as mean to evaluate $\mathrm{CFL}$ and other foreign language learning textbooks. Lastly, the results of this study will provide valuable input to the Department of Education, the Philippines in enhancing and improving the instructional materials being used in the implementation of Chinese Mandarin as a foreign language program.
\end{abstract}

Keywords Language Functions, Chinese as a Foreign Language (CFL), Textbook

\section{Introduction}

Since the establishment of the first Confucius Institute in 2004, learning Chinese Mandarin has become increasingly prevalent in the modern world. The rapid growth of China's economy as well as its exchanges with the world had contributed to the significant increase in the demand for Chinese language learning (Hanban, 2014). The number of non-native Chinese speakers learning Chinese as a foreign language (CFL) worldwide has been increasing (Du et al., 2017). Moreover, Chinese Mandarin has become a contender of the English language in the 21st century (Odinye, 2015). According to the 2017 annual report of the Confucius Institute (Hanban, 2017), at least 9.16 million students were learning Chinese Mandarin worldwide, including the CFL learners in the Philippines. Chinese Mandarin, along with Spanish, Japanese, French, German, and Korean, is being learned as a foreign language in the Philippine public high schools after it was included in the K-12 curriculum under the Special Program in Foreign Language in 2011. The program aims to enhance the learners' macro skills that are fundamental in acquiring communicative competence in a foreign language (Deped, 2017).

The concept of communicative language teaching has grown out of the notion that solely teaching grammar is not enough to prepare students for using the language independently. This method of teaching proposes that students need to understand the meaning and the communicative function of a language to learn the language (Bilash, 2009). This was supported by Krashen \&Terell (1983) who claimed that the most effective way of learning a language is by being exposed to the target language. The absence of the language environment in foreign language teaching hinders the learners from using the language. $\mathrm{Xu}$ and Yao (2014) identified two types of CFL learners: international students studying in China and students learning Chinese outside China. They added that CFL students overseas differ due to their linguistic, societal, and cultural contexts. Studies in Europe (Starr, 2009), 
Australia (Orton, 2008), and North America (Cruickshank \&Tsung, 2011) reported that one of the challenges in CFL is the decreasing motivation of CFL beginner learners, often causing lower retention rates. Foreign language learning involves a tedious and long process (Kilic, 2015). Green (1985) asserted that while it is significant for teachers to recognize the language students have when they enter school, still, teachers have the responsibility to help students increase their range of language competence by exposing students to different real-life situations. She added that dialogue with a more skillful language user plays a significant role in this procedure. The challenge for the CFL teachers outside China is to provide a language environment that would encourage CFL students to utilize the target language. The teacher should provide simulations inside the foreign language classroom, giving the learners the opportunity to utilize the target language in real-life scenarios (Krashen, 1981). Aside from imitating real-life scenarios, the use of varied instructional materials and technological devices can also provide inputs in foreign language learning (Ariza \& Hancock, 2003). Thus, language teachers are encouraged to help their students not only to read texts for information but to interpret them for their many layers of meaning (Kramsch, 2004).

Instructional materials, such as textbooks, play a vital role in language teaching and acquisition (Bahar\&Zaman, 2013). Rodriguez (2010) argued that above and beyond the mere study of linguistic forms, textbooks offer opportunities to communicate, interact, and negotiate meaning. The textbook is beneficial to teachers for its different purposes, such as resource material, source of classroom activities, or even a curriculum itself (Garinger, 2002). Richard (2001) stated that textbooks are a key component for any language program which served as a basis for the language inputs and language practice that language learners should receive in a language classroom. Textbooks are widely used in instructional materials both by the teachers and students (Tok, 2010). With the help of textbooks, students will learn the approach to use language for communication purpose rather than following the structure (Shaw\&Donough, 2003). On the other hand, Litz (as cited in Tok, 2010) argued that many scripted textbook language models and dialogues are unauthentic and inappropriate for communicative language teaching because they do not effectively prepare the students for the different real-life discourse. Richards \& Renandya (2002) mentioned that one of the weaknesses of a commercialized textbook in teaching is that it may contain inauthentic language. Moreover, according to Ansary \& Babaii (2002), no one textbook would fit all language learners, thus, there is always a need for the teacher to check for supplementary materials based on the needs and actual situation of the learners. Materials that can be supplemented with textbooks can be self-developed, localized, or adapted from different sources that would keep the language proficiency of the students (Awasthi, 2006).
Meanwhile, the identified textbooks used in the Philippines were one of the shortcomings in teaching CFL, because they were no longer updated and relevant to the students. (Go, n.d. as cited in Yu, 2000). Also, Yang (2014) asserted that non-uniform teaching materials and old-fashioned teaching methods are some of the several factors that affect teaching CFL in most schools in the Philippines. Teaching effect assessment is a comprehensive assessment system, and it is closely related to teaching materials, teaching strategies, and students' performance. Currently, the teaching materials used in Philippine public high schools are diversified because they mainly come from free books provided by the Chinese Mainland government and Taiwan Province. There are also charged textbooks coming from the Philippine Chinese Education Research Center, and few schools introduce relevant Chinese" teaching materials from Singapore and Malaysia. In line with this, the goal of this study is to evaluate the CFL textbooks used in the Philippine public high schools titled "Happy Chinese." As defined by Ellis (1997), textbook evaluation is the identification of the strengths and weaknesses of a particular textbook. It is a process of evaluation which is necessary for choosing the most appropriate material for the students. Cunningsworth (1995) claimed that one of the criterias in evaluating textbooks is that it should reflect the present or future uses which students will make of the language. It should be an aid for the students to use the language effectively for their own purposes. Crawford (2002) added that an effective material that will require students to use the language purposefully should contain a language which is functional, contextualized, realistic, and authentic. Halliday \& Matthiessen (2004) argued that language is primarily functional. The structure or form of language is important only to serve the function. This implies that without function, the structure would be completely pointless. Language is used for a variety of purposes whether formal and informal. The purposes in which students use language to communicate refer to the functions of the language or commonly known as language functions. There is a wide range of language functions and each language function explains why someone says something. Savignon (1983) described a language function as "the use to which language is put, the purpose of an utterance rather than the particular grammatical form an utterance takes." Tribus (2017) carefully scrutinize some widely used ESL and EFL textbooks, which revealed that these textbooks contain unequal and disproportionate language functions.

With this, the researcher decided to use Jakobson's six communicative functions. This model which was outlined in 1960 is a linguistic model relating to the communication between people or interpersonal communication. This highlights the importance of the social contexts and the codes involved in an utterance. Jakobson emphasized that six essential factors in verbal communication were necessary for communication to occur: (1) context, (2) 
addresser (sender), (3) addressee (receiver), (4) contact, (5) common code and (6) message. Jakobson proposed that each of these six factors (context, addresser, addressee, contact, code, and message) determines a particular linguistic function. These functions are (1) referential (2) emotive (3) conative (4) phatic (5) metalingual and (6) poetic. His model illustrates that messages as well as their meanings cannot be isolated from contextual factors. Moreover, Jakobson (1960) stated that language learners must investigate language functions and all types of their variety. He also asserted that one cannot develop a greater breadth of linguistic competency without being equipped with language functions. More importantly, Jakobson's model is an effective framework through which comprehensive aims of language can be investigated for richer ESL/EFL instruction and more comprehensive and effective use on the part of foreign language learners.

Among the six (6) language functions, the referential function is the most prominent. The reason for this is obvious, and people tend to start a conversation by giving a description or contextual information about things, places, and objects around them. For example, if you are in a new place and you are asking for a direction on how to get in a specific place, people will give you descriptions and characteristics of the place you are looking for, and the conversation will focus only on that matter. However, while these textbook publications recognized the eminence of the referential function, it does not represent the entirety of communication. It must be noted that not all communications involve description and contextual information alone. There are forms of communication that express emotion, clarify the meaning, or connect one information to another, and these are all equally important for the mastery of a specific language - in this case, Chinese. According to Tribus (2017), fluency in a specific language is a product of mastery of four domains namely: reading, writing, speaking, and listening. The fluency and true flexibility of communication will be achieved if someone masters the six language functions. A person cannot be considered fluent in a specific language if his capacity to express himself is limited and he barely capable of clarifying his thoughts. The researchers want to emphasize the importance of Jakobson's six communicative functions to help a student holistically enhance his fluency and linguistic competency. The six language functions contemplated by Jakobson will address the student's need to develop a wide variety of purposive communication. Hence, the researchers utilized Jakobson's six communicative functions to help students develop a greater breadth of linguistic competency.

The purpose of this study was to analyze the language functions embedded in each utterance in the dialogue sections of each lesson of the CFL textbooks Happy Chinese used by Philippine public high school students under the Special Program in Foreign Language (SPFL-Chinese Mandarin).
Specifically, the study sought to answer the following questions:

1. What were the language functions present in the textbooks?

2. How frequent were the language functions in the textbooks used?

2.1. What were the most observed language functions in the textbooks?

2.2. What were the least observed language functions in the textbooks?

3. Were all the language functions addressed in the textbooks?

4. What are the implications of this study to the teaching of Chinese as a Foreign Language in Philippine public high schools?

\section{Materials and Methods}

\subsection{Research Design}

This study utilized a mixed-methods research design. According to Leech (2008), mixed-methods research involves the collection, analysis, and interpretation of quantitative and qualitative data in a single study or a series of studies investigating the same underlying phenomenon. Hebert (2011) stated that in analyzing language functions, one should determine whether each of these functions of language is present or absent in a material. He added that, for communication to succeed, each factor must be present and congruent. This research involved the process of identifying the language functions present in the textbooks. The data in this study were gathered using a checklist. The checklists were divided into 1) dialogues that were obtained from textbooks 2) Jakobson's six language functions: referential, emotive, conative, phatic, metalinguistic and poetic and 3) remarks. The results of this study have been accomplished by careful inspection of the utterances in the dialogue sections in the textbooks. The researchers analyzed each utterance based on the factors of communication provided by Jakobson (1960). "Utterances may be truncated; that is, they may consist of single words or phrases (fragments) rather than fully formed clauses. In written language, utterances are termed as "sentences". The analyzed utterances were categorized into the most appropriate language function in Jakobson's communicative language function model. Moreover, this study also used a quantitative approach which involved the use of frequency distribution to identify the most observed and least observed language functions in the textbooks as well as to identify whether these language functions are fairly distributed or not.

\subsection{Materials}

Happy Chinese is a series of Chinese books that are 
suitable for elementary and high school students of English-speaking countries, which aims to develop communicative competence of CFL learners and to form a solid foundation for the learners' further study. It was developed by China's National Office for Teaching Chinese as a Foreign Language. The Happy Chinese has three (3) different levels - each level has a textbook, exercise book, and a teacher's manual. Each textbook is divided into eight (8) units, each with three (3) lessons. Each lesson in the textbooks corresponds to a particular topic that is supported through the use of dialogues. The main focus of this study is to evaluate the three textbooks present at all levels. These books are designed according to the psychological conditions and needs of students aged 11 to 16 years old with the requirements of foreign language curricula in their countries. Currently, the textbooks are used in the Philippine public high schools under the Special Program in Foreign Language (SPFL-Chinese Mandarin). The dialogues in each lesson of the books were extracted and analyzed using Jakobson's Six Communicative Language Functions.

\subsection{Instrument}

In this study, the checklist was used to categorize the utterances of the textbooks into Jakobson's six language functions. According to Freedet al (1991), a checklist is designed to provide general guidelines for conducting educational research. Moreover, Anderson (2000) defined a checklist as a list of questions or criteria that divides the areas of assessment into their main fields of application. In addition, a checklist also structures the evaluation of a certain performance. It can be marked by "yes" or "no"; "present" or "absent" and provides a space for the observer's remarks and suggestions. Hence, the person using the checklist can be familiarized with the proposed measure of all necessary data that has already been collected because a checklist is quick and easy to use. In this study, the checklist was divided into: (1) utterances that were obtained from the textbooks; (2) Jakobson's six language functions: referential, emotive, conative, phatic, metalinguistic and poetic; and (3) remarks.

According to Mojahan (2017), one of the most important and essential features in the evaluation of any instrument or tool for good research is validity. Fraenkel \& Wallen (2006) referred validity as the usefulness, correctness, meaningfulness, and appropriateness of any inferences a researcher draws based on data obtained through the use of an instrument. The instrument used in this study was validated by three (3) experts from the field of Language and Assessment. Their recommendations and suggestions served as bases for the revisions of the instrument.

Table 1. Jakobson's Six Communicative Functions of Language

\begin{tabular}{|c|c|c|c|}
\hline Classification & Strongest Factor & Function & Examples \\
\hline Referential & Context & description, contextual information & $\begin{array}{c}\text { Our business hours are 9am-5pm, Monday } \\
\text { through Friday. }\end{array}$ \\
\hline Emotive & Addresser & interjection/expressions of emotional state & $\begin{array}{c}\text { Oh, man... } \\
\text { Awesome! } \\
\text { Whew! }\end{array}$ \\
\hline Conative & Addressee & $\begin{array}{c}\text { concerned with demanding; vocative or } \\
\text { imperative addressing of the receiver }\end{array}$ & $\begin{array}{c}\text { Go on, open it! Shoo. Get out of here. Check } \\
\text { this out. }\end{array}$ \\
\hline Phatic & Contact & $\begin{array}{c}\text { concerns channels of communication; } \\
\text { performance social task as opposed to } \\
\text { conveying information; to establish, } \\
\text { prolong or discontinue conversation }\end{array}$ & $\begin{array}{c}\text { Hey! } \\
\text { Mmmm.. How about that? } \\
\text { Really? } \\
\text { No way! }\end{array}$ \\
\hline Metalinguistic & Code & $\begin{array}{c}\text { requires language analysis; using language } \\
\text { to discuss language }\end{array}$ & $\begin{array}{c}\text { Noun, adjective, } \\
\text { code-switching }\end{array}$ \\
\hline Poetic/Aesthetic & Message & $\begin{array}{c}\text { involves choosing words carefully, the art } \\
\text { of words, often self-reflective }\end{array}$ & $\begin{array}{c}\text { But, soft! } \\
\text { Whater is a non-count noun, right? }\end{array}$ \\
\hline
\end{tabular}




\subsection{Data Collection Procedure}

Initially, the Happy Chinese textbooks were borrowed from the Confucius Institute Library at Angeles University Foundation. Specifically, the dialogues per lesson of each book were gathered and translated into Chinese Romanization and English translations and were validated by Chinese language professors and by English language professors. The researchers also provided a rubric for face validation of the checklists and a rubric for the Chinese Romanization and English translations.

Table 2. Number of Utterances of Happy Chinese Textbooks

\begin{tabular}{|c|c|}
\hline Textbooks & Number of Utterances \\
\hline Happy Chinese Textbook 1 & 50 \\
\hline Happy Chinese Textbook 2 & 148 \\
\hline Happy Chinese Textbook 3 & 205 \\
\hline Total & 403 \\
\hline
\end{tabular}

Table 2 displays the number of utterances collected from the dialogue sections of the textbooks. The Happy Chinese (textbook 1) has 50 utterances, the Happy Chinese (textbook 2) has 148 utterances and the Happy Chinese (textbook 3) has 205 utterances. These utterances were carefully analyzed and categorized by the researcher under its most appropriate function from Jakobson's six (6) communicative language function model.

\section{Results and Discussion}

\subsection{Results}

Table 3. Frequency and Percentage of Language Functions in Happy Chinese

\begin{tabular}{|c|c|c|c|c|c|c|}
\hline & \multicolumn{2}{|c|}{$\begin{array}{c}\text { Textbook 1 } \\
\text { (N=62) }\end{array}$} & \multicolumn{2}{c|}{$\begin{array}{c}\text { Textbook 2 } \\
\text { (N=189) }\end{array}$} & \multicolumn{2}{c|}{$\begin{array}{c}\text { Textbook 3 } \\
\text { (N= 247) }\end{array}$} \\
\hline & $\mathrm{f}$ & $\%$ & $\mathrm{f}$ & $\%$ & $\mathrm{f}$ & $\%$ \\
\hline Referential & 34 & 54.84 & 90 & 47.62 & 73 & 29.55 \\
\hline Emotive & 4 & 6.45 & 15 & 7.94 & 21 & 8.50 \\
\hline Conative & 2 & 3.23 & 18 & 9.52 & 39 & 15.79 \\
\hline Phatic & 22 & 35.48 & 64 & 33.86 & 94 & 38.06 \\
\hline Metalinguistic & 0 & 0.00 & 0 & 0.00 & 0 & 0.0 \\
\hline Poetic & 0 & 0.00 & 2 & 1.06 & 20 & 8.1 \\
\hline
\end{tabular}

Table 3 reveals the descriptive statistics for the frequency and percentage of the language functions used in the textbooks. $\mathrm{N}$ refers to the number of language functions. For Textbook 1, the language functions present are referential, phatic emotive, and conative. In this textbook, $54.84 \%$ of utterances are referential, $6.45 \%$ are emotive, $3.23 \%$ are conative, $35.48 \%$ are phatic, and $0 \%$ is metalinguistic and poetic. Looking at this table, one can conclude that the most observed language function in this textbook is referential which covers $54.84 \%$, and the least observed language functions are metalinguistic, $0 \%$ and poetic $0 \%$.

Next, the language functions present in Textbook 2 are referential, phatic, conative, emotive, and poetic. In this textbook, $47.62 \%$ of utterances are referential, $7.94 \%$ are emotive, $9.52 \%$ are conative, $33.86 \%$ are phatic, $0 \%$ is metalinguistic and $1.06 \%$ is poetic. Therefore, the most observed language function in Textbook 2 is referential, i.e. $47.62 \%$ and the least observed is metalinguistic, i.e. $0 \%$.

While, the language functions present in Textbook 3 are referential, phatic, conative, emotive and poetic. In this textbook, $29.55 \%$ of utterances are referential, $8.50 \%$ are emotive, $15.79 \%$ are conative, $38.06 \%$ are phatic, $0 \%$ is metalinguistic and $8.01 \%$ are poetic. Therefore, the most observed language function in Textbook 3 is Phatic, i.e. $38.06 \%$ and the least observed is metalinguistic, i.e. $0 \%$.

Looking at the results of Table 3, it can be inferred that the language functions are not at the same or even close in frequency, which means that not all language functions are distributed fairly in the dialogue sections of each textbook. This implies that the textbooks in terms of their communicative ability do not provide comprehensive support for all the six (6) language functions.

\subsubsection{Pedagogical Implication}

According to DepEd, the number of public high schools with foreign language programs is steadily increasing. Yang (2014) stated that in terms of teaching way, due to the complex structure of Chinese teaching staff, the teachers' teaching way, teaching level, and teaching effect are all different. While students struggle in learning the language, teachers also face challenges in teaching students. Some high-level teachers with rich experience can quickly bring students into the Chinese world and realize the quick growth of students' Chinese level. However, as for some teachers with insufficient teaching experience, due to lack of professional training in language teaching, they still use traditional teaching way in Chinese Mainland and regard overseas Chinese students in the Philippines as Chinese mother-tongue students for teaching. Thus resulting in the situation that the teachers talk too much, but the students practice little. The teaching is dull, and the learning and practice are detached - there is more mechanical memorizing than flexible use. This implies that CFL students in the Philippines are in a passive, receptive mode listening as the teacher teaches. However, language is functional (Jakobson \& Mathiessen, 2004). Memorizing the structure of the language would be completely pointless without being taught how to deal with language functions. According to Dornyei \& Ryan (2015), Svalberg (2009), the key step to process foreign language learning is engagement. Fredricks, Blumenfeld, \& Paris (2004) defined engagement as a concept that describes students' behavior, cognition, and emotions while in class. By being 
engaged in different communicative activities, students develop long-term motivation in learning a foreign language. In addition, by being exposed to communicative activities in the classroom, students will also be aware of the purposes the language serves resulting in a more meaningful and effective communication.

Textbooks are key components in most language programs (Richard, 2001). However, this study showed that Happy Chinese textbooks, which are used in teaching Mandarin in Philippine public high schools, do not address all the six communicative language functions, which are significant in developing greater breadth of linguistic competency of foreign language learners. Richard (2001) also added that textbooks may serve as a form of teacher training because they provide ideas on how to plan and teach lessons as well as formats that teachers can use. By taking the pitfalls of the dialogue sections of these textbooks, teachers in the Philippine public high school under the Special Program for Foreign Language - Mandarin can adjust their pedagogical strategy to suit the needs of their particular groups of students. Because of students' multicultural background, the diversity of experience that language learners bring to the classroom could mean that they interpret the same material in a very special way. Teachers can celebrate these differences by enriching the materials for the whole class (Tribus, 2017). Written texts, such as textbooks, are the solid wellspring of a language program. These materials can serve as the basis for language development only if the teacher provides instructional assistance. Therefore, teachers play a critical role in supporting the development of language. They need to help kids learn and use language aspects in different contexts. They need to help them become more aware of how language works in different communication modes throughout the curriculum and different subjects. Teachers need to understand how language works well enough to select materials to help expand the linguistic horizons of their students and to plan educational activities that provide opportunities for students to use the new forms and modes of expression they are exposed to (Fillmore et al, 2000).

\subsection{Discussion}

According to some language experts like Malinowski (1935), Firth (1957), Jakobson (1960), Halliday (1975) Savignon (1983), Kumpulainen \& Wray (1997) and Fontaine (2013), language functions help language learners achieve a wide variety of meaning potential within a given context. Therefore, in order to understand the meaning of a conversation, language learners need not only the knowledge of the structure of language but they likewise need to be aware of the purposes that language serves.

The frequency of the language functions in the textbooks is the first point to be discussed. The results of this study showed that out of six (6) language functions in Jakobson's communicative language function model, referential is the language function that appeared the most in the conversation sections of Textbooks 1 and 2, while the most observed language function in Textbook 3 is phatic. The referential function is the common language function in ESL/EFL settings because it concerns descriptions or contextual information. The finding of this study is supported by the investigation of Darali (2007) that the textbook titled 'Spectrum Series' provided different language functions. However, the language functions e.g. promising, threatening, vowing, were not as frequent as others. Consequently, the result is also similar to the study of Kohandani, Farzaneh, and Kazemi (2014) that there is no imaginative function in Top Notch 1 and the language functions in the conversations were of varied frequencies. In Jakobson's “The Speech Event and the Functions of Language (1995), he explained, "although we distinguish six basic aspects of language, we could, however, hardly find verbal messages that would fulfill only one function." This implies that the utterances may be perceived and their functions may be classified differently, but at least one of the six functions in Jakobson's model will always be present and essential to effective communication. $\mathrm{He}$ also added that while referential is the leading task of numerous messages, it is also necessary to take into account the accessory participation of other functions in such messages. Tribus (2017) also stated that referential function is prevalent in daily conversation, but it is a disservice to language learners to ignore the other five language functions.

This study also revealed that metalinguistic and poetic are not present in Textbook 1 and metalinguistic function is not present in Textbooks 2 and 3. Jakobson (1960) defined metalinguistic function as a function concerned with the utterances that deals with language itself. For Jakobson, as cited in Linask (2018), the appearance of metalinguistic function and talk about language are closely tied to the development of clauses with an explicit grammatical subject and an explicit grammatical predicate. The three (3) textbooks of the Happy Chinese are designed to develop the basic communicative competence of the CFL learners, specifically, it is paralleled with the competencies of Chinese Proficiency Test level 1 (HSK 1). CFL learners in the HSK 1 level can understand the most basic, simple, and limited materials related to common personal and daily life (Xu, 2014). Thus, metalinguistic function or the ability to talk about the language was not present in all three (3) materials. The metalinguistic function is not only an essential part of the early language but also for second language acquisition. The lack of a metalinguistic function will hinder students to talk about semantic or grammatical structures. Moreover, without this function, students will not be able to navigate challenging or unclear communication thus, resulting in poor understanding of communication strategies to repair 
misunderstandings between participants.

Furthermore, Table 3 showed that while there is a $0 \%$ poetic function in textbook $1,1.06 \%$ poetic functions present textbook 2 , and $8.1 \%$ poetic functions in textbook 3. Taking into account this increase in poetic function in Textbooks 2 and 3, the reason may lie in the greater complexity involving the creation of some new units and topics (in this book, sentences). Fillmore et al (2000) stated that textbooks on child development often claim that children have a long way to develop functions before they can be as mature members of their speech communities. This implies that as children progress through the grades, which also results in the development of their language proficiency, and they acquire more sophisticated aspects of language through the use of challenging topics. Being equipped with the poetic or aesthetic function will help students explore more on the similarities and differences between uses of words which eventually help them choose which words they could put together to make an utterance more meaningful and interesting.

Although Table 3 illustrates that there were only two language functions i.e. metalinguistic and poetic, that were absent, still, the other language functions i.e. phatic, emotive, and conative, were not fairly distributed in the textbooks. Jakobson (1960) identified phatic function as the first verbal function that infants acquire; they are likely to communicate before sending or receiving informative communication. In this study, the phatic function appeared as the second most observed language function in Textbooks 1 and 2, and the most observed in Textbook 3. Jakobson emphasized that with the knowledge of phatic function, a student can be able to establish and even prolong communication with others. The presence or absence of phatic function can have a profound impact upon the relationship that is built and strengthened between speakers. Students can engage in a small talk whose purpose relates to the connection between speakers because it is phatic in function. While phatic function focused on establishing communication between two different speakers, the emotive function also known as "expressive function" is focused on producing an impression on a certain emotion. It is often manifested by the use of interjection. Pavlenko (2007) said that the absence of this communicative function not only deprives the language learner of the ability to engage emotionally with another speaker, but also may reduce the possibility of expression, retention, or development of a fully formed L2 identity, further hindering his or her ability to communicate effectively. It is more concerned with giving conceptual meaning rather than connotative meaning. On the other hand, the conative function is defined in terms of the effects of the message on the addressee's behavior, according to Serban (2012). Besides, the conative function of language or, more generally, communication focused on and concerned with influencing the addressee's behavior and thus concerned with persuasion. It is also concerned with the receiver's command; vocational or imperative addressing. Tribus (2017) said that this function is important to learners to familiarize them to the structures and types of imperatives.

A good dialogue, with fair distribution throughout the textbook, addresses all language functions (Halliday, 2009). He discussed that although there are limited types of language functions in many cases of real communications and authentic conversations, there might be no need to apply all their types. However, he also argued that to make learners pragmatically competent in their speech performance, a good textbook must include conversations containing all types of these language functions distributed fairly throughout the dialogues sections of the textbooks. In other words, the presence of all the language functions and the distribution of these language functions in a material cannot be denied. Students use language functions to communicate with others, express ideas, and show understanding of content. Jakobson (1960) as cited in Tribus (2017) argued that addressing all six functions will provide students with a broader understanding of the varied purposes language serves and dedicated attention to Jakobson's six communicative functions of language will allow language learners to develop a fuller range of communicative ability.

\subsection{Conclusions}

Based on the findings of this study, the researchers concluded the following:

1. The language functions present in Textbook 1 are: referential, phatic, conative, and emotive, while in the Happy Chinese Textbooks 2 and 3 are referential, phatic, emotive, conative, and poetic.

2. The most observed language function in Textbooks 1 and 2 is referential, while phatic is the most observed language function in Textbook 3 . The least observed language functions in Textbook 1 are metalinguistic and poetic, while the least observed language function in Textbook 2 and 3 is metalinguistic.

3. The language functions in the dialogue sections of Happy Chinese textbooks are not distributed fairly which means they are not at the same or close in frequency. This implies that the textbooks in terms of their communicative ability do not provide comprehensive support for all the six (6) language functions.

\subsection{Recommendations}

Based on the results and the conclusions of this study, researchers hope that the following would be a useful reference to explore more on the problems and solutions in the area of language learning and pedagogy, 
development and designing of instructional materials and even in the analysis of conversations and dialogues of other teaching materials. Below are the recommendations of the researchers:

1. Textbook developers can take the communicative shortfalls of the dialogues of Happy Chinese into consideration as a useful source to design and develop other CFL textbooks.

2. This study recommends the developers and the editors of Happy Chinese to take the reportedly missing language functions into consideration and fairly distribute all language functions in the dialogue sections of the textbooks.

3. This study provides valuable input to the Department of Education that can be used in enhancing and improving the implementation of Mandarin as a foreign language program here in the Philippines.

4. The present study also suggests that CFL teachers should engage students in different communicative activities that will help them be aware of the purpose of communication as a sort of remedy to the lacking language functions in Happy Chinese textbooks.

5. Based on the increase of poetic function in the textbooks, as shown in Table 3, the researchers may explore the relationship of language proficiency level and acquisition of language functions or the relationship between the age of learners and language functions.

\section{REFERENCES}

[1] Ansary, H., \&Babaii, E. (2002). Universal characteristics of EFL/ESL textbooks: A step towards systematic textbook evaluation. The Internet TESL Journal, 8(2), 1-9.

[2] Ariza, E. N., \& Hancock, S. (2003). Second language acquisition theories as a framework for creating distance learning courses. The International Review of Research in Open and Distributed Learning, 4(2).

[3] Awasthi, J. R. (2006). Textbook and its Evaluation. Journal of NELTA, 11(1-2), 1-10.

[4] Bahar, H. B., \& Zaman, B. (2013). Significance of Text Book Evaluation for the Purpose of Effective Second Language Acquisition. ISOR Journal of Humanities and Social Science, 12(5), 70-77.

[5] Bilash, O. (2009). Improve your classroom practice through action research-Become a researcher of your own instruction. Ihla Newsletter, 6(3), 8-22.

[6] Couture, B. (1986). Bridging epistemologies and methodologies: research in written language function.

[7] Crawford, J. (2002). Role of materials in language classroom: Finding the balance. In J.C Richards \& W.A Renandya,
(Eds.), Anthology of current practice. (pp.84-87) Port Melbourne, Australia: Cambridge University Press

[8] Cruickshank, K., \& Tsung, L. (2011). Teaching and learning Chinese: A research agenda. In L. Tsung, \& K. Cruickshank (Eds.), Learning and teaching Chinese in global Contexts: Multimodality and literacy in the new media age (pp. 213e224). Bloomsbury Publishing.

[9] Cunningsworth, A. (1995). Choosing your coursebook. Heinemann.

[10] Darali, G. (2007). Pragmatics dimension in Spectrum textbooks. Unpublished master's thesis, Shiraz University, Iran.

[11] Dornyei, Z., \& Ryan, S. (2015). € The psychology of the language learner revisited. New York: Routledge.

[12] Du, X., Zhao, K., Ruan, Y., Wang, L., \& Duan, X. (2017). Beginner CFL learners' perceptions of language difficulty in a task-based teaching and learning (TBTL) environment in Denmark. System, 69, 108-120.Fraenkel, J.R. and Wallen, N.E. (2006). How to Design and Evaluate Research in Education. New York: McGraw-Hill.

[13] Ellis, R. (1997). The empirical evaluation of language teaching materials. ELT journal, 51(1), 36-42.

[14] Fillmore, L. W., \& Snow, C. E. (2000). What teachers need to know about language.

[15] Fontaine, L. M. (2013). Semantic options and complex functions: A recursive view of choice.

[16] Fraenkel, J. R., \& Wallen, N. E. (2006). How to design and evaluate research in education.

[17] Fredricks, J. A., Blumenfeld, P., \& Paris, A. H. (2004). School engagement: Potential of the concept, state of the evidence. Review of Educational Research, 74(1), 59e109. http://dx.doi.org/10.3102/00346543074001059.

[18] Freed, M. N., Ryan, J. M., \& Hess, R. K. (1991). Handbook of statistical procedures and their computer applications to education and the behavioral sciences. Macmillan Publishing Co, Inc.

[19] Garinger, D. (2002). Textbook selection for the ESL classroom. Center for Applied Linguistics Digest. Savignon, S. J. (1983). Communicative competence: theory and classroom practice. Reading.

[20] Gómez-Rodríguez, L. F. (2010). English Textbooks for Teaching and Learning English as a Foreign Language: Do They Really Help to Develop Communicative Competence? Educación y Educadores, 13(3), 327-346.

[21] Green, J. L. (1985). When you get the right answer to the wrong question: Observing and understanding communication in classrooms. NCTE and IRA Joint Committee on the Impact of Child Language Development Research on Curriculum, 221.

[22] Halliday, M. A. (1975). Language as social semiotic: towards a general sociolinguistic theory. In The first LACUS forum (pp. 17-46). Hornbeam Press.

[23] Halliday, M. A. K., \& Webster, J. J. (Eds.). (2009). Bloomsbury companion to systemic functional linguistics. A\&C Black. 
[24] Halliday, M. A. K., Matthiessen, C., \& Halliday, M. (2014). An introduction to functional grammar. Routledge.

[25] Hébert, L. (2011). The functions of language. Signo.

[26] Jakobson, R. (1960). Linguistics and poetics. In Style in language (pp. 350-377). MA: MIT Press.

[27] Jakobson, R. (1990). The speech event and the functions of language. On language, 69-79.

[28] Kilıç, V. (2015). Language functions and distance learning. International Journal of Media Culture and Literature, 1(1), $11-21$.

[29] Krashen, S. D. (1981). Second language acquisition and second language learning. Oxford University Press.

[30] Krashen, S. D., \& Terrell, T. D. (1983). The natural approach: Language acquisition in the classroom.

[31] Kramsch, C. (2004). Language, thought, and culture. In A. Davies, \& C. Elder (Eds.), The handbook of applied linguistics (pp. 235-265). London and New York: Blackwell Publishers. doi:10.1002/9780470757000.ch9.

[32] Koh, E. T., \& Owen, W. L. (2000). Descriptive research and qualitative research. In Introduction to Nutrition and Health Research (pp. 219-248). Springer, Boston, MA.

[33] Kohandani, M., Farzaneh, N., \&Kazemi, M. (2014). A critical analysis of speech acts and language functions in Top Notch series. Procedia-Social and Behavioral Sciences, 98, 1009-1015.

[34] Kumpulainen, K., \& Wray, D. (1997). Functional Analysis of Children's Classroom Talk: A framework for understanding children's discourse in educational contexts. In A paper presented at the 1997 American Educational Research Association Conference, Chicago.

[35] Leech N, Onwuegbuzie A, (2008) A typology of mixed methods research designs, Quality and Quantity, 43(2), March, pp. 265-275.

[36] Litz, D. R. (2005). Textbook evaluation and ELT management: A South Korean case study. Asian EFL journal, $48,1-53$.

[37] Linask, L. (2018). Differentiation of language functions during language acquisition based on Roman Jakobson's

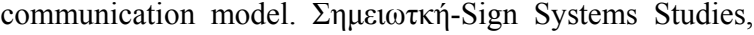
46(4), 517-537.

[38] Malinowski, B. (1935). An ethnographic theory of language. Coral gardens and their magic, 2(Part IV).
[39] Mohajan, H. K. (2017). Two criteria for good measurements in research: Validity and reliability. Annals of SpiruHaret University. Economic Series, 17(4), 59-82.

[40] Odinye, S. I. (2015). The spread of Mandarin Chinese as a global language. Nnamdi Azikiwe University.

[41] Orton, J. (2008). Chinese language education in Australian schools: October 2008. University of Melbourne.

[42] Palanca, E. H. (2002). A comparative study of Chinese education in the Philippines and Malaysia. Asian Studies Journal of Critical Perspective on Asia, 38(2), 29-62.

[43] Patton, M. Q. (2003). Utilization-focused evaluation. In International handbook of educational evaluation (pp. 223-242). Springer, Dordrecht.

[44] Pavlenko, A. (2007). Autobiographic narratives as data in applied linguistics. Applied linguistics, 28(2), 163-188.

[45] Richards, J. C. (2001). The role of textbooks in a language program. RELC Guidelines, 23(2), 12-16.

[46] Tavakoli, F. (1995). Functional analysis of the dialogues in the Iranian senior high school English textbooks. Unpublished master's thesis. Allameh University, Tehran.

[47] Tok, H. (2010). TEFL textbook evaluation: From teachers' perspectives. Educational Research and Reviews, 5(9), 508.

[48] Tribus, A. C. (2017). The Communicative Functions of Language: An Exploration of Roman Jakobson's Theory in TESOL.

[49] Tsur, R. (2010). The poetic function and aesthetic qualities: cognitive poetics and the Jakobsonian model. Acta Linguistica Hafniensia, 42(S1), 2-19.

[50] Shaw, J. M., \& Mc Donough, J. (2003). Materials and methods in ELT. A teachers guide: Wiley-Blackwell.

[51] Starr, D. (2009). Chinese language education in Europe: The confucius institutes. European Journal of Education, 44(1), $65 \mathrm{e} 82$.

[52] Yang, S. (2014, November). Several Thoughts on Current Chinese Education in the Philippines. In 2014 International Conference on Education Technology and Social Science. Atlantis Press.

[53] Yu, J. V. B. (2000). Inculturation of Filipino-Chinese Culture Mentality (Vol. 3). Gregorian Biblical BookShop.

[54] Xu, X., \& Yao, L. (2014). A survey of students' motivation with language-character integration approach and language-character separation approach. Teaching Chinese to Speakers of Other Languages Studies, 3, 8e16. 